\title{
USE OF CHECK SHEET ON DATA MANAGEMENT OF BUSINESS ACTIVITIES TO IMPROVE BUSINESS EFFECTIVENESS AND EFFICIENCY AT SMI MERUYA SELATAN - WEST JAKARTA
}

\author{
Lien Herliani KUSUMAH*, and Henni GUSFA \\ Universitas Mercu Buana Jakarta, Indonesia. \\ *lien.herliani@mercubuana.ac.id
}

\begin{abstract}
This activity has the purpose to provide knowledge, understanding and practices for entrepreneurs to collect and analyses business activity data using check sheets. Participants in this activity are entrepreneurs and stakeholders of small and medium industry (SMI) in the Meruya Selatan Village, Kembangan District, West Jakarta. The method of activities to be used in training activities and implementation of check sheet are online lecture, discussion, and question and answer, online questionnaire (pre-test and posttest), and practice. Participation and seriousness of the participants is good enough. Result of this training is entrepreneurs and stakeholders feel satisfied and get practical knowledge about using check sheet on data management of business activities.
\end{abstract}

Keywords: Data Management, Check Sheet, Small and Medium Industry (SMI)

\section{BACKGROUND}

Small and medium industry (SMI) has a strategic role in the national economy. SMI has a vital role as the backbone of the national economy; they can even stand upright when global economic conditions are unstable. SMI is the majority sector of the industrial population in Indonesia. So far, his activities have consistently brought about overall multiplier effects to promote equal social welfare distribution. This can be seen from the number of business units in 2019 where the Ministry of Industry noted that the number of small and medium-sized industries (SMI) in Indonesia reached 44 million units and constituted more than $90 \%$ of the national industrial business units. Data from the Central Statistics Agency (BPS) shows that growth comes $17 \%$ every year, most dominant in Java. This role is also reflected in the absorption of SMI's workforce, which absorbs up to 11.68 million people or $60 \%$ of the non-oil and gas industry sector's total employment. The small industry is the focus of the government because its growth in Indonesia is quite fast.

SMI also has a large variety of products, can fill a large market area, and becomes a source of income for the wider community and has resistance to various crises. With these characteristics, the growth and development of SMI will contribute significantly to realizing a robust and advanced national economy characterized by democracy.

However, the Ministry of Industry also noted that $99 \%$ of these SMIs experienced difficulties developing their businesses. Several problems faced by SMI are limited digital marketing capabilities, unstable production, supply chain management, and data management that can increase business effectiveness and efficiency.

Data management is crucial for every business activity, including SMI. Poor data management, resulting in at least poor management, shows that the company is less organized. Moreover, vice versa, that good data management will help companies achieve targets according to planning. Management of company data, of course, begins with the availability of accurate data sourced from the right data sources.
Every business that is already running should have a data source that can be useful for business progress. A simple form (document) that helps SMIs collect and analyze their business data is a check sheet (Juran Institute, 1990; Bothe, 2001; Rooney et al., 2009; Cartia, 2014; Ahmad et al., 2018).

A check sheet is a structured, prepared form (document) for collecting and analyzing data in real-time at the location where the data is generated. A check sheet is a generic data collection and analysis tool that can be adapted for a wide variety of purposes. The check sheet is one of the so-called Seven Basic Tools of Quality Control (Tague, 2004) from Ishikawa. He is one of Quality Gurus.

Universitas Mercu Buana, especially the Master Program of Industrial Engineering (Prodi MTI) tries to participate in developing the competitiveness of SMI in West Jakarta specifically to encourage data management capabilities. Especially in collecting and analyzing data on business activities to increase the effectiveness and efficiency of its business. This program is based on observations. It is concluded that the data management capability is still low in the SMI of Meruya Selatan Village, West Jakarta, which is the guidance of the West Jakarta Sub-Department of Industry and Energy (PE).

This activity aims to provide knowledge, understanding and practices for entrepreneurs at SMI Meruya Selatan to collect and analyses business activity data using check sheets. It is hoped that the results of this activity will allow SMIs to manage data from their business activities to encourage increased business effectiveness and efficiency. Improvement of the overall performance of SMI must start from the ability to collect data from their business activities so that they can encourage the competitiveness of the SMI business itself.

\section{METHOD}

The public targeted in this community dedication is entrepreneurs and stakeholders of small and medium industry. The training was conducted in January 2021. 


\section{Participants}

Participants of this activity are entrepreneurs and stakeholders of small and medium industry (SMI) in the Meruya Selatan Village, Kembangan District, West Jakarta.

\section{Approach}

Method of training are: Online Lecture, Discussion, and Question and Answer; Online Questionnaire (Pre-test and Post Test); and Online Practice. (See Figure 1.)

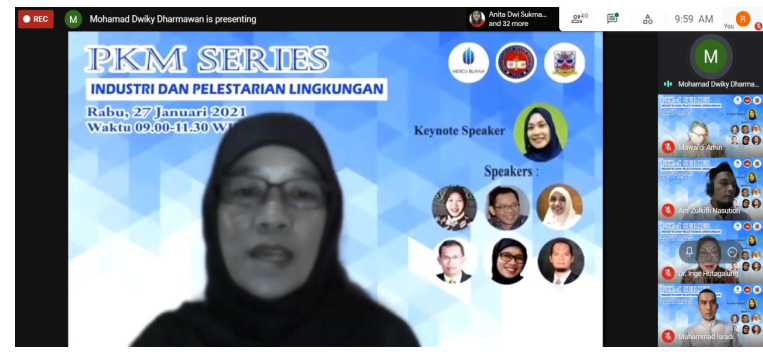

Figure 1. Online method

Materials of the training is about management of company data and using check sheets (Figure 2).

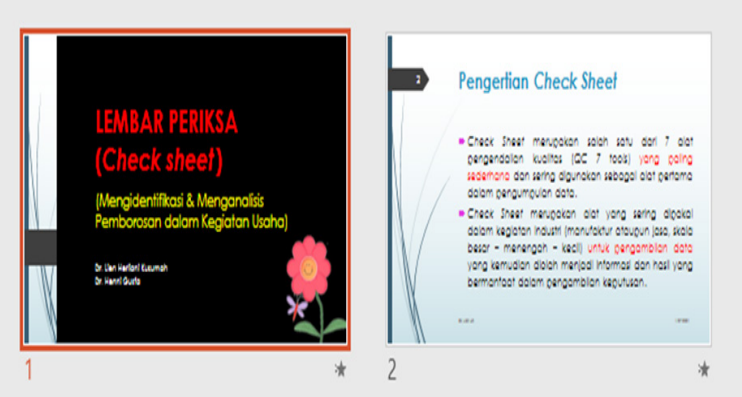

Figure 2. Part of slide material

The implementation of this activity is socialization and training in nature so the hope is that participants can recognize and understand the importance of managing data on business activities as a basis for reference in making business decisions. Moreover, improve the abilities, needs, interests, and habits of SMI entrepreneurs in managing business activity data by using check sheets.

\section{RESULT AND DISCUSSION}

\section{Result}

Result of this community dedication is described in three aspects; those are participants' attendance, participation and seriousness of participants.

Participants 'attendance. Participants of this activity are small and medium industrial entrepreneurs in South Meruya, West Jakarta. In conducting the activity the number of attended participants are 49 (forty-nine) people in one day session. Activities take place in several places while still complying with health protocols in this new normal era (see Figure 3). This is so that participants can focus on participating in the entire series of activities.

Participation and seriousness of participants. It can be said that participation and seriousness of participants are good. This was seen from seriousness of participants in following the activities of delivering material, participation of opinion, as well as questions answer.

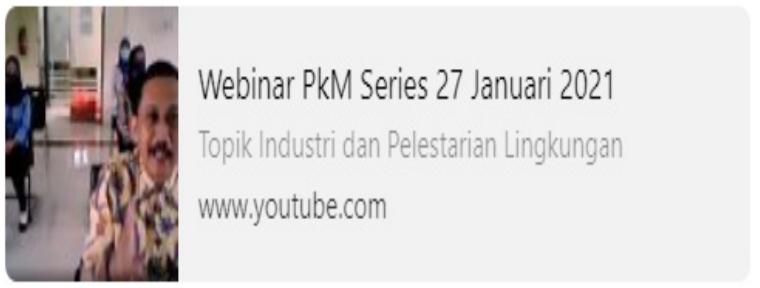

Figure 3. Participants enthusiastically attended while maintaining health protocols

Exposure to socialization and training materials includes:

\section{Management of company data}

Data about a company's activities if appropriately managed, can support many strategic decisions for the company, even in the end, it can help the company achieve the desired targets. Some of the benefits of data management that can help make management decisions, both strategic and related to the management and implementation of strategies, are:

Improving operational efficiency. Managing company data can produce information that can be used to make essential decisions quickly and save time. Reports is made remotely and can respond to a problem based on data that has been processed quickly.

Increasing company innovation in business. Data management and utilization can enhance the company's brand with the right innovation according to consumer desires, and increase customer trust. This achievement is the impact of the company's ability to process data into a source of information with an appropriate and measurable system.

Assisting management decision making. Data management that is integrated into the management information system will provide benefits for leadership in making decisions so that they are no longer subjective. Management will be more objective because it is based on processed data.

Every business that is already running should have a data source that can be used for business progress. A simple form (document) that helps SMI collect and analyses its business data is a check sheet (Juran Institute, 1990; Bothe, 2001; Rooney et al., 2009; Cartia, 2014; Ahmad et al., 2018).

\section{Check sheet}

A check sheet is a structured, prepared form (document) for collecting and analyzing data in real-time at the location where the data is generated. A check sheet is a generic data collection and analysis tool that can be adapted for a wide variety of purposes. The check sheet is one of the so-called Seven Basic Tools of Quality Control (Tague, 2004) from Ishikawa. He is one of Quality Gurus. The data it captures can be quantitative or qualitative. When the information is quantitative, the check sheet is sometimes called a tally sheet (Schultz, 2006). 
When using a check sheet? When data can be observed and collected repeatedly by the same person or at the same location. When collecting data on the frequency or patterns of events, problems, defects, defect location, defect causes, or similar issues. In addition, when collecting data from a production process.

\section{Discussion}

Check Sheet is one of the seven most simple quality control tools (QC 7 tools) and is often used as the first tool in data collection. Check Sheet is a tool that is often used in industrial activities (manufacturing or services, largemedium-small scale) for data collection, which is then processed into useful information and results in decisionmaking.

Using of check sheets are: To observe and collect data repeatedly by the same person or at the same location. To collect data from the production process. In addition, to collect data about the frequency or pattern of events, problems, defects, location of defects, causes of defects, or similar problems.

Check sheet procedure are the first; determine what events or problems will be investigated. Second, determine when the data will be retrieved and how long it will take. Third, designing the format. Forth, try or test the check sheet in draft form (concept script) to make sure the check sheet is easy to use and includes all the data we need. Fifth, make changes if needed. Finally, fill in the data every time the incident or problem that we are researching occurs. Example of check sheet in Figure 4.

Results of the training evaluation are:

1. Does the webinar material open up your thoughts? (100\% answered agree)

2. Does the webinar material increase knowledge? $(100 \%$ answered agree)

3. Does the webinar material improve understanding in identifying waste in business activities? $(100 \%$ answered agree)

4. Does the webinar material help overcome the problem of waste in business activities? (100\% answered agree)

5. Do webinars need to be held on an ongoing basis? (100\% answered agree)

6. Does the webinar time need to be extend? (59.18\% answered agree and $40.82 \%$ answered disagree)

\section{CONCLUSION AND SUGGESTION Conclusion}

Community service activities have been carried out in the form of socialization and training on company data management and the use of check sheets to improve business effectiveness and efficiency at SMI Meruya Selatan - West Jakarta. The results of this training indicated that the participants were satisfied. Small and medium industry entrepreneurs understand the management of company data and the use of check sheets.

\section{Suggestion}

The socialization and training activities on management of company data should be given on a scheduled basis because it is very relevant and has many benefits for small and medium industrial entrepreneurs.

\section{REFERENCES}

Ahmad, M. F., Yin, J. C. S., Nor, N. H. M., Wei, C. S., Hassan, M. F., Hamid, N. A., \& Ahmad, A. N. A. (2018, September). The relationship between TQM tools and organisation performance in the small and medium enterprise (SMEs). In AIP Conference Proceedings (Vol. 2016, No. 1, p. 020017). AIP Publishing LLC.

Bothe, D. R. (2001). Use check sheets to identify the causes of downtime. Quality Progress, 34(4), 136.

\section{Terjadi Kerusakan/Kesalahan Produk}

\begin{tabular}{|c|c|c|c|c|c|}
\hline \multirow{2}{*}{ Jenis } & \multicolumn{4}{|c|}{ Hari } & \multirow{2}{*}{ Total } \\
\hline & $08: 00-10: 00$ & $10: 00-12: 00$ & $13: 00-15: 00$ & $15: 00-17: 00$ & \\
\hline Bentuk & & 1 & I & & 2 \\
\hline Warna & I & & & & 1 \\
\hline Ukuran & I & 1 & 1 & $I$ & 4 \\
\hline Total & 2 & 2 & 2 & 1 & 7 \\
\hline
\end{tabular}

\begin{tabular}{|c|c|c|c|}
\hline \multicolumn{4}{|c|}{ CONTOH CHECK SHEET UNTUK KERUSAKAN } \\
\hline \multicolumn{2}{|l|}{$\begin{array}{l}\text { Produk } \\
\text { Lokasi } \\
\text { Hari Tgl }\end{array}$} & \multirow{2}{*}{$\begin{array}{l}\text { Pukul } \\
\text { Pekeria } \\
\text { Pengawas } \\
\text { Parat } \\
\text { ikan }\end{array}$} & 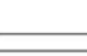 \\
\hline \multicolumn{3}{|c|}{$\begin{array}{l}\text { Petunjuk Pengisian: } \\
\text { - Beri tanda lidi (I) untuk setiap kerusakan } \\
\text { pada kolom Frekuensi } \\
\text { - Tulis jumlah lidi pada kolom jumlah }\end{array}$} & \\
\hline No & $\begin{array}{l}\text { Jenis Kerusakan/ } \\
\text { Kesalahan }\end{array}$ & Frekuensi & Jumlah \\
\hline 1 & Bentuk & "1 & 2 \\
\hline 2 & Warna & I & 1 \\
\hline \multirow[t]{2}{*}{3} & Ukuran & IIII & 4 \\
\hline & & Total Kerusakan & 7 \\
\hline
\end{tabular}

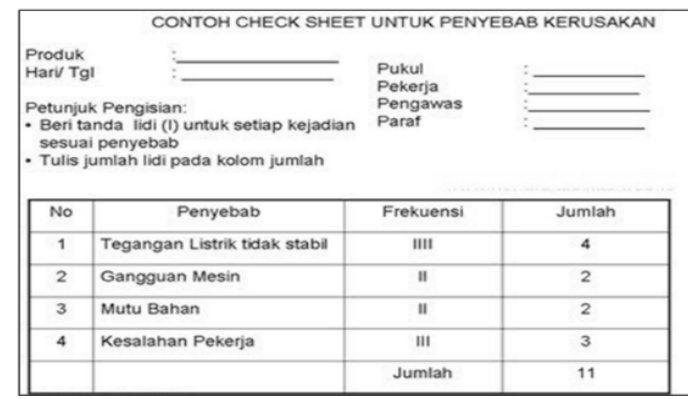

Figure 4. Example of check sheet 
Cartia, R. A. (2014). At your fingertips. Quality Progress, 47(3), 24.

Juran Institute Inc. (1990). The Tools of Quality, Part V: Check Sheets. Quality Progress, 51-56.

Nancy R. Tague (2004). "Seven Basic Quality Tools”. The Quality Toolbox. Milwaukee, Wisconsin: American Society for Quality. p. 15. Retrieved 2010-02-05
Rooney, J. J., Kubiah, T. M., Westcott, R., Reid, R. D., Wagoner, K., Pylipow, P. E., \& Plsek, P. (2009). Building from the basics. Quality Progress, 1, 18-29.

Schultz, J. R. (2006). Measuring service industry performance: Some basic concepts. Performance Improvement, 45(4), 13.

Vardiansyah, Dani. (2008). Filsafat Ilmu Komunikasi: Suatu Pengantar, Indeks, Jakarta. 